\title{
Mario Vargas Llosa'nın Lituma en los Andes Adlı Romanında Anlatının Yapısı
}

\section{The Narrative Structure in the Novel Death in the Andes by Mario Vargas Llosa}

\author{
Neslihan KADIKÖYLÜ1
}

'Lecturer, Dr., Anadolu University, Foreign Languages School, Department of Modern Languages, Eskişehir, Turkey

ORCID: N.K. 0000-0002-0167-6702

\section{Corresponding author:}

Neslihan KADIKÖYLÜ,

Anadolu Üniversitesi, Yabancı Diller Yüksekokulu, Modern Diller Bölümü, Eskişehir, Türkiye

E-mail: nkadikoylu@anadolu.edu.tr

Submitted: 22.03 .2021

Revision Requested: 29.05.2021

Last Revision Received: 23.07.2021 Accepted: 20.08.2021

Citation: Kadikoylu, N. (2021). Mario Vargas Llosa'nın Lituma en los Andes adlı romanında anlatının yapısı. Litera, 31(2), 715-731.

https://doi.org/10.26650/LITERA2021-900746 öz

Bu çalışmada, Mario Vargas Llosa'nın Lituma en los Andes (And Dağları'nda Terör) adlı romanındaki anlatı yapısı; anlatıcı, anlatı kipleri ve zamansal çerçeve gibi öğeler açısından incelenmektedir. 1960 'ı yıllarda ortaya çıkan ve Latin Amerika Edebiyatı'nın dünya çapında dikkat çekmesini sağlayan "boom" adlı dönemin yazarlarından biri olan Mario Vargas Llosa yapıtlarında yenilikçi teknikleri ustalıkla kullanır. 1993 yılında yayımladığı And Dağları'nda Terör adlı eseri de öykü içinde öyküleri, labirenti andıran yapısal özellikleri ve kurgusu bakımından zengin bir yapıttır. Romanda ana öykü, And'larda bir dağ köyü olan Naccos'taki bir karakolda görevli olan Çavuş Lituma ile yardımcısı Er Tomás'ın kısa bir süre önce kaybolmuş olan üç kişiyi bulmaya ve aslında ne olduğunu çözmeye çalışması etrafında şekillenir. Lituma'nın bu iz sürme macerası ise anlatıyı bir yandan Aydınlık Yol (Sendero Luminoso) gerillalarının bölgede yarattığı terör ortamına, diğer yandan ise gulyabaniler, apular gibi efsanelere götürür. Anlatıda, zaman ve bakış açısında yapılan değişikliklerle birçok başka öykünün de aralara serpiştirildiği ve her birinin, geçmiş ile şimdi arasında geçişler yapılarak yazar tarafından ustaca örüldüğü görülür. Bu bağlamda çalışmanın amacı, Fransız düşünür Gérard Genette'in Anlatının Söylemi: Yöntem Hakkında Bir Deneme adlı eserinde etraflıca ele aldığı ve Marcel Proust'un Kayıp Zamanın Izinde adlı eserine uyguladığı yöntemi ana hatlarıla açıklamak ve And Dağları'nda Terör romanını bu teoriye göre inceleyerek eserin yapısını ortaya koymaktır.

Anahtar Kelimeler: Mario Vargas Llosa, And Dağları'nda Terör, Latin Amerika edebiyatı, Gérard Genette, anlatının söylemi

\section{ABSTRACT}

This study examines the narrative structure in Mario Vargas Llosa's novel Death in the Andes in terms of elements such as the narrator, narrative modes and temporal framework. Vargas Llosa, one of the authors of the so called "boom" period, which emerged in the 1960s and made Latin American literature attract worldwide attention, skillfully uses innovative techniques in his works. His novel Death in the Andes, published in 1993, offers a multi-layered lecture by presenting a story within the story, a labyrinthine structure and fiction. In the novel, the main story revolves around Sergeant Lituma and his deputy Tomás, who are on duty at a police station in Naccos, a mountain village in the Andes, trying to find three people who had recently disappeared and figure out what actually happened. Lituma's adventure of investigation takes the 
narration to the terror environment created by the Shining Path (Sendero Luminoso) guerrillas in the region and also to legends such as ghouls and apus. Also, it's seen that the author brings together many different stories and skillfully connects them using transitions between the past and present. In this context, the aim of the study is firstly to outline the method elaborated by the French philosopher Gérard Genette in his book The Narrative Discourse An Essay in Method and applied to the novel In Search of Lost Time by Marcel Proust, and secondly to examine the novel Death in the Andes according to this theory.

Keywords: Mario Vargas Llosa, Death in the Andes, Latin American literature, Gérard Genette, narrative discourse

\section{EXTENDED ABSTRACT}

This study aims to analyze the narrative structure in Mario Vargas Llosa's novel Death in the Andes according to Order, Duration, Frequency, Mode and Voice, the terms stated by Gérard Genette in his theory of Narrative Discourse, and to reveal different aspects of the novel.

Mario Vargas Llosa, one of the Nobel prize-winning authors of the era named "boom", which emerged in the 1960s and made Latin American literature attract worldwide attention, skillfully uses innovative techniques in his works. His novel Death in the Andes, published in 1993, offers a multi-layered lecture by presenting a story within the story, a labyrinthine structure and a strong fiction. In the novel, the main story revolves around Sergeant Lituma and his deputy Tomás, who are on duty at a police station in Naccos, a mountain village in the Andes, trying to find three people who had recently disappeared and figure out what actually happened. Lituma's adventure of investigation takes the narration to the terror environment created by the Shining Path (Sendero Luminoso) guerrillas in the region and also to legends such as ghouls and apus. Also, the author brings together many different stories and skillfully connects them using transitions between the past and present. In this context, the aim of the study is firstly to outline the method elaborated by the French literary theorist Gérard Genette in his work The Narrative Discourse An Essay in Method and applied to the novel In Search of Lost Time by Marcel Proust, and secondly to examine the novel Death in the Andes according to this theory.

The first and most prominent aspect of the novel is its complex and immersive structure in which the intertwined stories follow a labyrinthine structure. These stories, which emerged during the investigation carried out by Lituma, are the most important elements that enable the narration to become more labyrinthine and bring together different times and spaces. Thus, in the first parts of the work, it's thought that the kidnappers might be the Shining Path guerrillas, while in the following pages, a more 
complex framework is formed by including legends and supernatural beings in the narration. Many other supernatural stories, such as the story of the ghoul Salcedo, told by Doña Adriana, suggest that supernatural forces might be the cause of the disappearances, while the executions and acts of violence by the Shining Path continue in the area. The protagonist of the novel increasingly falls into doubts and questions in this investigation -until everything is clear at the end of the story- and drags the reader with him through the narration.

Finally, another striking structural feature observed in the novel is that the narrator, in some episodes, conveys what happened in different times and places to the same point and narrates them in an intertwined manner. Vargas Llosa calls this technique, which he uses in many of his other novels, the communicating vessels. This technique, which allows creating stories within the story, also opens the way for a narration in the form of Chinese boxes. In the novel, the change of the narrator in the second parts of the 6 th, 7th, 8th and 9th chapters, and the transformation of Doña Adriana, one of the characters of the narration, into a first-person narrator can also be evaluated as a result of these techniques. Also, these chapters, which tell the story of Dionisio and the murder of the ghoul Salcedo, take place at the metadiegetic level and, as Genette defined, there is a direct causality between the events of this meta-story and the main story. 


\section{Giriş}

"iktidar biçimlerini ayrıntılarıyla göstermesi ve bireyin direniş, isyan ve yenilgilerinin keskin tasvirlerini yapması" ("Mario Vargas Llosa", 2021) sebebiyle 2010 yılında kendisine Nobel Edebiyat Ödülü verilen Mario Vargas Llosa, roman sanatı üzerine düşünen, bu doğrultuda eleştiri kitapları kaleme alan, hayatını yoğun bir biçimde yazmaya adayan ve birçok türde eserler veren çok yönlü, bütünlüklü bir yazardır. 28 Mart 1936 yılında Peru'nun Arequipa kentinde Ernesto Vargas Maldonado ile seçkin bir aileden gelen Dora Llosa Ureta'nın tek çocuğu olarak dünyaya gelir. İlk gençlik yıllarında, baskıcı bir babanın zorlamasıyla kayıt olduğu askeri okulda geçen yıllar onun edebiyata sıkı bağlarla kenetlenmesini sağlar. Üniversite yıllarında ise, kendisini edebi teknik ve anlatım özellikleri açısından geliştirecek olan Sartre, Flaubert, Faulkner gibi yazarlarla tanışır ve bu yazarların eserlerinden oldukça etkilenir. 1963 yılında, ilk romanı La ciudad y los perros (Kent ve Köpekler) ile birlikte edebiyat çevrelerinde adını duyuracağı bir süreç başlar. Bu yıllar aynı zamanda üslup yönünden büyük bir dönüşüm anlamına gelen ve Latin Amerika yazınının kapılarını dünyaya açan "boom" adlı dönemin başlangıcıdır. Gabriel García Márquez, Miguel Ángel Asturias, Carlos Fuentes, Alejo Carpentier gibi yazarların yapıtlarıyla yükselen edebi birikimin patlama yıllarıdır ve Vargas Llosa'nın Kent ve Köpekler'i de bu dönemi temsil eden önemli yapıtlar arasında yerini alır (Sanabria, 2011, s. 2). Yazar eserlerinde toplumsal eleştiri temasını yenilikçi bir üslup, yapı ve teknikle ele alır ve standart tiplemelerin, kronolojik sıranın ya da tanrısal yazar anlayışının dışına çıkarak yeni bakış açıları, anlatım tarzları dener. Ayrıca birçok romanında, 1997 yılında yazdığı ve anlatıdaki biçim, üslup, anlatıcı, zaman, mekan gibi unsurları geniş bir biçimle ele aldığı Cartas a un joven novelista (Genç Bir Romancıya Mektuplar) adlı eserinde değinmiş olduğu dört anlatım tekniğini (bileşik kaplar tekniği, matruşka tekniği, dönüşümler, gizli bilgi) kullanarak anlatıyı zenginleştirdiği görülür.

Yazarın çalışmamıza konu olan romanı And Dağları'nda Terör Peru'nun dağlık bölgelerinde, özellikle de Naccos adlı köyde geçer. Burası eski bir maden kampının bulunduğu ve bir süre önce başlayan yol inşaatının da devam etmekte olduğu uzak bir dağ köyüdür. Ana olay örgüsü, Aydınlık Yol gerillalarının bölgede yarattığı terör ortamı içinde karakolda görev yapmakta olan Çavuş Lituma ile jandarma eri Tomás'ın köyde esrarengiz bir biçimde kaybolan üç kişiyi bulmak amacıyla yürüttükleri soruşturmadır. Ayrıca, eski inanç ve geleneklerin sürdürüldüğü bu yerde mitolojik unsurlar taşıyan öyküler ve gerçekleşen esrarengiz olaylar da anlatıya dahil edilir. Kaybolan kişilerin akıbetleri, şantiyedeki işçiler ve diğer köylüler tarafından, gulyabani ve apular gibi And 
Dağları bölgesine özgü efsanelere dayandırılır. Bu çerçevede esere iki şiddet unsurunun hakim olduğu görülür: Aydınlık Yol gerillalarının gerçekleştirdiği saldırı ve infazlar ile dağlardaki ruhlara ve tanrılara insan kurban etmeyi içeren mitolojik inançlar. Öte yandan, kayıpların izinin sürüldüğü bu ana öyküye paralel olarak Tomás ile Mercedes arasında yaşanan aşk hikayesi de anlatılır. Anlatıda yer alan diğer öyküler ise, iki Fransız turistin, Casimiro Huarcaya'nın, Medardo Llantac'ın, Pedro Tinoco'nun ve Bayan d'Harcourt'un başlarından geçen olaylardır. Anlatı, öykü içinde öyküleri ve labirenti andıran yapısal özellikleri ve kurgusu bakımından zengin bir yapıya sahiptir. Tüm öyküler zamansal ve odaksal değişikliklerle iç içe geçmiş ve her biri, geçmiş ile şimdi arasında geçişler/ sıçramalar yapılarak yazar tarafından ustaca örülmüştür. Anlatının bu hareketli yapısından yola çıkarak eseri anlatının söylemi teorisine göre incelemeye çalışacağız'.

\section{Yöntemsel Çerçeve: Anlatının Söylemi}

Çalışmamızda anlatının iç yapısına yönelerek eseri anlatıcı, anlatı kipleri ve zamansal çerçeve gibi açılardan ele alarak incelemeyi hedefledik. Analizin temelinde Fransız yapısalcılığının önemli isimlerinden Gérard Genette'in Anlatının Söylemi (2011) adlı yapıtında açıkladığı zaman kategorisinde yer alan düzen, süre ve sıklık ile kip ve ses tanımlamalarını takip ederek anlatının yapısını ortaya çıkarmak yer almaktadır.

Genette söz konusu eserinde Proust'un Kayıp Zamanın Izinde adlı roman serisini inceler ve çözümlemesini yapar. Kayıp Zamanın Izinde'nin yalnızca kendi kendinin örneği eşsiz bir yapıt olduğunu ancak diğer yandan da eserin sahip olduğu özgüllüğünün ayrıştırılamaz olmadığını ifade eder. Burada bir analiz yöntemi sunduğunu, tikel olana yönelmekle evrensel olanı bulacağını ve anakroni, odaklanma, paralipsis diye adlandırdığı genel ve yaygın kullanımdaki tekniklere ulaşacağını vurgular (2011, s. 11). Genette gösterilen ya da anlatısal içerik için hikaye sözcüğünü; gösteren, bildirim, söylem ya da

1 And Dağları́nda Terör eseri üzerine yapılmış incelemeler genellikle anlatıdaki şiddet öğelerini ve mitolojik unsurları incelemektedir. Bu konuda daha fazla okuma yapmak için bkz.: Bortoluzzi, M. (2013). El mito del Pistacho en Lituma en los Andes de Mario Vargas Llosa. Mitologías hoy, 8, 93-114; Luque Laguna, A. M. (1999). Diálogos Entrecruzados y Apoteosis de la Violencia en Lituma en los Andes. Revista de Filología Hispánica, 15 (2), 439-450; Penuel, A. M. (1995). Intertextuality and the Theme of Violence in Vargas Llosa's Lituma en los Andes. Revista de Estudios Hispánicos, 29 (3), 441-460. Ayrıca eserin ayrıntılı incelemesi için bkz.: Piazza de la Luz, I. (2017). El ciclo serrano de Mario Vargas Llosa: Historia de Mayta y Lituma en los Andes. Alicante: Universidad de Alicante. Eserin anlatıbilim açısından incelemeleri için ise bkz.: Cristina del Solar, M. (2008). Aproximaciones narratológicas a Lituma en los Andes de Mario Vargas Llosa. D. Altamiranda ve E. Smith (Ed.). IV Simposio de Narratología içinde (s. 245-251). Buenos Aires: Editorial Dunken ile Berg, M. G. (1995). Narrative Multiplicity in Vargas Llosa's Lituma en los Andes. C. J. Paolini (Ed.). XVI. Louisiana Conference on Hispanic Languages and Literatures içinde (s. 25-38). New Orleans: Tulane University. 
bizzat anlatı metni için anlatı sözcüğünü ve anlatısal eylem üretimi için ise anlatılama sözcüğünü kullanır. Anlatı söylemi analizinin ise özünde, anlatı ile hikaye, anlatı ile anlatılama ve hikaye ile anlatılama arasındaki ilişkileri incelemeyi içerdiğini ifade eder (2011, s. 15-17). Bu çerçevede eseri, düzen, süre, sıklık, kip ve ses olmak üzere beş ana başlık altında inceler. Bu başlıkları da kendi içinde üç bölüme ayırır. Düzen, süre ve sıklık anlatının zamansal çerçevesini ortaya koyarken, kip anlatı temsilinin biçimi ve dereceleri ile ilgili noktaları ve son olarak ses ise anlatılama edimini ifade eder (2011, s. 19-20).

Genette'in eserin zamansal çerçevesini ortaya koymak için önerdiği üç başlık temelde şu üç soru ile özetlenebilir: Ne zaman? (düzen), Ne kadar? (süre) ve Hangi sıklıkta? (sıklık) (Dervişcemaloğlu, 2016, s. 163). Düzen başığı altında olayların sıralanışı, diğer bir deyişle anlatının zamansal düzeni ele alııır ve anakroni kavramı ön plandadır. Genette kronolojik sırayı takip etmeyen ve bu sırayı geriye dönüş ya da öngörüler ile bozan anlatı düzenini anakronik olarak tanımlar. Anlatıcının, öykünün o anda bulunduğu zamansal noktaya göre önceden olmuş bir olayı anlatması anlamına gelen geriye dönüş yerine analepsis terimini, sonradan olacakları anlatması anlamına gelen öngörü ya da ileri atlama yerine de prolepsis terimini kullanır (2011, s. 24-28). Analepsis anlatıda açıklayıcı bir rol üstlenebilirken prolepsis daha ileride açığa çıkacak olaylarla ilgili okurda merak uyandırabilir.

Süre ifadesiyle ise anlatının hızına değinilmektedir. Genette hız kelimesiyle zamansal boyut ile mekansal boyut arasındaki ilişkiyi kastettiğini yazar. Buna göre, "anlatının hızı (hikayenin saniyeler, dakikalar, saatler, günler, aylar, yıllar şeklinde ölçülen) süresi ile (metnin satırlar, sayfalar şeklinde ölçülen) uzunluğu arasındaki ilişki üzerinden tanımlanır" (2011, s. 84-85). Anlatının hızı (ya da ritmi) da kendi içinde dört kola ayrııı: Özet (anlatııııın olayları özetleyerek anlatıma hız katması), ara (anlatıcının öyküden ayrılıp yorum ve betimlemeler yaparak ritmi düşürmesi), eksilti (anlatıcının öyküde geçen bazı olayları aktarırken zamanda sıçramalar yaparak anlatıma hız katması) ve sahne (anlatıcının olayları ayrıntılandırıp doğrudan aktararak ritmi düşürmesi) (Kıran ve Kıran, 2011, s. 227).

Zamansal çerçeveyi inceleyen diğer başılı ise sıklıktır. Anlatı ile hikaye arasındaki tekrarları ifade eder, diğer bir deyişle, bir olayın öykü içinde kaç kez meydana geldiğini ve kaç kez anlatıldığını inceler. Bu çerçevede Genette dört tür sıklık ilişkisi belirlemiştir. Buna göre herhangi bir anlatıda, bir kere olmuş bir şeyin bir defa (örneğin, dün yatmaya erken gittim cümlesi), $n$ kere olmuş bir şeyin $n$ defa (Pazartesi yatmaya gittim, Salı yatmaya 
gittim, Çarşamba yatmaya gittim), bir kere olmuş bir şeyin $n$ defa (Dün yatmaya erken gittim, dün geç olmadan yatmaya gittim, dün erkenden kendimi yatağa attım, vb.), $n$ kere olmuş bir şeyin bir defa (her gün, bütün hafta ya da hafta boyunca her gün yatağa erken yattım, vb.) anlatılabileceğini belirtir. Ilk iki durumu tekilci anlatı (ikinci durum, öyküdeki yineleme, anlatıdaki yinelemeyle örtüştüğü için tekilcidir), diğer durumları da sırasıyla tekrar eden anlatı ve yinelemeli anlatı olarak adlandırır (2011, s. 116-119).

Kip ve ses bölümlerinde ise anlatım ve anlatıcı konusu ön plandadır. Ses anlatıma, kip ise perspektife (görünge) atıfta bulunur. Buna göre anlatıcı ile odaklayıcı birbirinden farklı anlatım unsurlarına karşıık gelirler (Çıraklı, 2015, s. 44): "Her ikisi aynı entitede buluşabildiği gibi, farklı entitelerde de karşımıza çıkabilir. Anlatııı aynı zamanda bir tür odaklayıcıdır. Kimi zaman karakterler odaklayıcı olarak belirir. Anlatıya hakim bakış açısı ya da görüş açısı, 'anlatıcı ses kime ait, anlatan kim?' sorusuna ek olarak 'olayları gören göz kime ait, algılayan kim, odaklayıcı kim?' sorusuna da ihtiyaç duyar" (s. 44).

Genette bir anlatıda yalnızca olumlama, emretme, isteme vb. arasında değil, aynı zamanda olumlamanın dereceleri arasında da farklılıklar olduğunu ve bu farkların kipe dayalı çeşitliliklerle ifade edildiğini söyler (2011, s. 171). Daha açık bir söyleyişle, “(...) bir insan anlattığı şeyi $a z$ ya da çok anlatabilir ve dahası şu ya da bu bakış açısına göre anlatabilir; bu kapasite ve onun kullanımının kiplikleri, tam da bizim anlatı kipi kategorisiyle kastettiğimiz şeydir" der (2011, s. 171-172). Özetle kip, anlatının sunulma biçiminin nasıl olduğu ile ilgilidir ve bu başlık altında anlatıcının konumunu gösteren mesafe, perspektif ve odaklanma olmak üzere üç kavram yer alır.

Mesafe, en temelinde anlatıının anlatıdaki varlığının ve mesafesinin derecelerini ifade eder. Diğer bir deyişle, Genette bu kavram ile anlatııı ile öykü arasındaki mesafeyi belirleyici olarak alır ve buna göre mesafe, anlatıda yer alan kesinlik derecesi ile iletilen bilginin doğruluğunun belirlenmesine katkı sağlar (Dervişcemaloğlu, 2016, s. 72). Buradan hareketle Genette karakterlerin konuşmalarının (sesli ya da iç) üç hali arasında ayrım yapar ve bunları anlatı mesafesine bağlar: Anlatılı ya da anlatılan konuşma ("Anneme Albertine'le evlenmeye karar verdiğimi söyledim"), dolaylı tarzda yeri değiştirilmiş konuşma ("Albertine'le kesinlikle evlenmem gerektiğini düşündüm") ve dolaysız konuşma (“Anneme, Albertine'le kesinlikle evlenmem lazım, dedim") (2011, s. 182-184). Anlatı perspektifi ise, metinde "kim görüyor?" sorusunun yanıtı olarak karşımıza çıkar ve bakış açısını, diğer bir deyişle "anlatı perspektifini yönlendiren karakterin kim olduğunu" (2011, s. 199) ifade eder. 
Bakış açısı için odaklanma sözcüğünü kullanan ve odaklanmayı "tercihe dayalı olarak yapılan bir alan sınırlaması" (Dervişcemaloğlu, 2016, s. 98) şeklinde ifade eden Genette üç çeşit odaklanma tanımlar: Sıfır odaklanma, dışsal odaklanma ve içsel odaklanma. Sıfır odaklanmalı anlatıda, anlatıcı karakterlerden daha çok bilgi sahibidir; tüm zamanların içinde ve her yerdedir. Roman kişilerinin düşüncelerini, niyetlerini, geçmiş ve geleceklerini bilir ve aynı anda farklı mekanlarda yaşanan olayları betimleyebilir. Dışsal odaklanmada, anlatıcı anlatının kahramanlarından daha az bilen nesnel bir dış tanık konumundadır. Yorum yapmaktan kaçınır; olayları nesnel bir biçimde, tamamen dışarıdan birinin gözlemleriyle aktarır. İçsel odaklanmada ise anlatıc bir kahramanın kimliğine bürünerek, bu kahramanın düşündüğü, hissettiği ve yaptığı şeyleri anlatır. Anlatıcının bilgisi, kahramanın bakış açısı ile sınırlıdır; okur da aynı şekilde her şeyi bu kahramanın gözleriyle görür, onun düşüncelerini paylaşır (Kıran ve Kıran, 2011, s. 142-145). Buna göre bakış açısı temelde filtreleme kavramı ile paralel ilerler: "Öykü, belli şeyleri anlatı uzayının dışında bırakacak, belli şeylere ise daha çok ışık tutacaktır. Filtrelemeyi mümkün kılan şeyse perspektifin (görünge) mevcut olmasıdır. Bu üç kavram, görünge, filtreleme ve bakış açısı şeklinde sıralanabilir. Burada görünge sebebe, filtreleme sürece, bakış açısıysa sonuca tekabül eder" (Çıraklı, 2015, s. 43).

Son olarak ses başlığında ise şahıs, anlatılama zamanı ve anlatı düzeyleri kavramları açıklanır. Genette şahıs alt başlığında doğrudan anlatıcıya yer verir ve anlatıcının öyküde yer alıp almadığını değerlendirir. Anlatıcının öyküde yer almadığı anlatıları heterodiegetik, anlatıcının anlattığı öyküde bir karakter olarak var olduğu anlatıları ise homodiegetik olarak adlandırır (2011, s. 267-268). Diğer alt başlık olan anlatılama zamanı, anlatıcının öyküye göre zamansal konumunun ne olduğunu ifade eder. Bu bağlamda Genette, sonradan, önceden, eşzamanlı ve araya giren öyküleme olmak üzere dört ayrı öyküleme türü belirler. Sonradan öyküleme en sık rastlanan türdür. Öyküleme olaylar bittikten sonra yapılır ve klasik bir geçmiş zaman anlatısıdır. Olaylar başlamadan önce, genellikle gelecek zaman kipinde, bazen de şimdiki zamanla birleşmiş olarak yapılan öyküleme ise önceden öykülemedir. Anlatı içinde kahramanın gelecekle ilgili planlarının ya da düşlerinin anlatıldığı bu yöntem daha çok bilim-kurgu romanlarında görülür. Eşzamanlı öykülemede, kurmaca zamanı ile öyküleme zamanı çakışır ve şimdiki zaman ya da geniş zaman kullanılır. Son olarak, araya giren öykülemede ise, anlatıcı, belli bir şimdiki zamanı sıfır noktası alarak, ileriye giderek ya da geriye dönerek olayları aktarır. Mektup biçimindeki romanlar ve günlükler buna örnek verilebilir (2011, s. 234-235). Anlatı düzeyleri ise ana öyküye başka olayların eklenmesiyle oluşan ve anlatıyı oluşturan farklı seviyelerdir, hikayelerin iç içe geçtiği durumlarda birbirleri ile ilişkilerini tanımlamak için kullanılır. 
Buna göre, hikayenin dışındaki anlatıcı dış-öyküsel (extradiegetik) düzeyde yer alır. Bu ilk anlatının içinde anlatılan olaylar ise öyküsel veya iç-öyküsel (intradiegetik) düzey olarak tanımlanır. Genette ikinci derece anlatılara ise üst-öyküsel (metadiegetik) düzey adını verir (2011, s. 248).

\section{And Dağları'nda Terör'de Anlatının Yapısı}

\section{Zamansal Çerçeve (Düzen, Süre, Sıklık)}

Anlatı iki kısım ile bir sonsözden (epilog) oluşur. Illk kısım 1-5 arası bölümleri içerirken ikinci kısım 6-9 arası bölümlerden oluşur. 10. bölüm ise sonsöz kısmıdır. Metin, anlatının düzeni, diğer bir deyişle olayların sıralanışı açısından değerlendirildiğinde birçok bölümde anlatıcının, anakronik bir anlatı düzenine başvurarak kurmacanın süredizimsel sırasını bozduğu görülür. Her bölümde, birbiriyle bağlantılı olan ve farklı açılardan birbirini tamamlayan öykülerin anlatıldığı üç ayrı anlatı yer alır. Ana olay örgüsü olan birinci anlatı, kaybolan üçüncü kişi olan Medardo Llantac'ın karısının öğlen saatlerinde karakola gelip dört gündür kocasının kayıp olduğunu bildirmesi ile başlar (Vargas Llosa, 1996, s. 11). Köydeki ilk kayıp vakası olan Pedro Tinoco üç hafta önce ortadan kaybolmuştur: "Öyleyse onları dağlar mı yutmuştu? Aradan üç hafta geçtiği halde Çavuş Lituma'yla jandarma eri Tomás Carreño bu konuda ilk gündeki kadar bilgisizdiler" (Vargas Llosa, 1996, s. 12). Lituma'nın Naccos'a ne zaman geldiği ise belirsizdir, ilerleyen bölümlerde anlaşıldığı kadarıyla aylardır bu dağ köyündeki karakolda görev yapmaktadır: "Burada geçirdiği aylar boyunca..." (Vargas Llosa, 1996, s. 81).

Her bölümde, ana olay örgüsünü oluşturan birinci anlatı dışında iki anlatı daha bulunur ve birinci anlatı kronolojik olarak belli bir sırayı takip ederken ikinci ve üçüncü anlatının zamansal düzeni tam olarak net değildir. İkinci anlatıda karmaşık bir yol izlenir; zamanda ileri ya da geri gidişlerle kronolojik sıra bozulur. Eserin ilk kısmındaki (1-5 arası bölümlerdeki) ikinci anlatılar sırasıyla Andahuaylas'taki otobüs saldırısını (1), Pedro Tinoco'nun hikayesini (2), Andamarca'ya gerçekleşen saldırıyı (3), Bayan d'Harcourt ve beraberindekilerin öldürülmesini (4) ve Casimiro Huarcaya'nın öyküsünü (5) anlatır. Bu öykülerin her biri birbiriyle bağlantılı olmasına karşın farklı zamanlarda gerçekleşmiş olaylardır ve kronolojik bir sıra izlemezler. Örneğin 3. bölümün ikinci anlatısı olan Andamarca saldırısı ana öykünün başlangıç zamanından daha gerilere uzanan dışsal bir analepsis örneğidir. Zira eser Medardo Llantac'ın Naccos'ta kayboluşuyla başlamıştır ancak bu bölümde Llantac'ın Naccos'a gelişinden öncesi anlatılır. Eserin ikinci kısmındaki 
(6-9 arası bölümlerdeki) ikinci anlatılar ise Doña Adriana'nın ben anlatım konumunda yer aldığı anlatılardır. Kendi içinde zamansal bir düzeni takip etmesine karşın, bu bölümler yine dışsal birer analepsis örneğidir. Burada öykü Naccos'ta maden ocağının açık olduğu geçmişe gider ve bugüne kadar uzanır.

1. bölümden başlayıp sonsöze kadar süren üçüncü anlatı ise karakolda -çoğunlukla gece- Tomás ile Lituma arasında geçen sohbeti konu eder. Tomás, Lituma'ya aşkı Mercedes ile tanışmasını ve yaşadıkları birkaç haftalık olayları anlatır. Bu anlatının zamanı da çok net değildir. Örneğin 5. bölümün birinci anlatısında Lituma'nın La Esperanza'ya gitmeye hazırlandığını, 6. bölümün birinci anlatısında da buna uygun olarak Lituma'nın La Esperanza'da olduğunu okuruz. Ancak söz konusu bölümlerin üçüncü anlatılarının, Naccos'taki karakolda gece gerçekleşiyor olması iki anlatının birbiriyle ilişkisinin kronolojik olmadığını gösterir: "Ben uyuyacağım Tomasito, artık uykum geldi, senin öykünden de sıkıldım" (Vargas Llosa, 1996, s. 140). Öte yandan, 7. bölümün birinci anlatısında gerçekleşen çığ felaketi, bir sonraki bölümün 3. anlatısında da geçer ve çığdan sonraki bir zamanın anlatılmakta olduğunu belli eder. Bu kez iki anlatı, kronolojik açıdan birbirini takip edecek şekilde ilerlemiş olur: "Bakalım o lanet olasıca çığın korkusunu böylece üstümden atabilecek miyim?" (Vargas Llosa, 1996, s. 210).

Görüldüğü gibi, bazı ipuçları takip edilerek kısmen çıkarımlarda bulunulabilse de özellikle ikinci anlatının Doña Adriana bölümlerinin ve üçüncü anlatının, ana olay örgüsü olan birinci anlatıya göre zamansal olarak nerede konumlandığı çoğu kez belirsiz ve karmaşıktır. Örneğin, 1. bölümün 2. anlatısındaki Andahuaylas otobüs saldırısının ne zaman gerçekleştiği 2. bölümün 1. anlatısında geçer: "Bir gece önce Dionisio'nun meyhanesindeyken Andahuaylas otobüsüne yapılan saldırı haberi duyulmuş (...)"(Vargas Llosa, 1996, s. 32). Böylece okurda kronolojik sıra takip ediliyormuş izlenimi uyanır; ancak daha sonra, 2. bölümün 2. anlatısında, metin otobüs saldırısının devamını anlatmaz ve yeni bir konuya geçilir. Pedro Tinoco'nun hikayesi anlatılır ve bambaşka bir zaman ve mekan söz konusudur. Burada da yine dışsal bir analepsis araya girerek Pedro Tinoco'nun çocukluğundan başlayarak Aydınlık Yolcularla karşılaşmasına kadar geçen uzun bir geçmiş anlatılır: "Pedro Tinoco'ya çocukluğundan beri kaçık, gerzek, kafadan kontak, ahmak, hep ağzı açık dolaştığı için de ayran budalası derlerdi" (Vargas Llosa, 1996, s. 42).

Nihayet sonsöz kısmı ise tek bir anlatı şeklinde karşımıza çıkar. Çığ felaketinden birkaç gün sonrası anlatılır. Lituma karakoldadır ve Mercedes'in gelişiyle meyhaneye 
gitmek üzere oradan ayrılır. Meyhanede geçen gecenin ardından oradaki bir işçi ile yaptığı konuşma neticesinde kaybolan üç kişiye ne olduğunun aydınlanması ile eser tamamlanır: "-Ayin gereği hepsi yediler, istemediğim halde ben de yedim- dedi işçi acele acele-. Beni kahreden de bu. Yuttuğum onca lokma" (Vargas Llosa, 1996, s. 263).

Süre açısından ise metinde Genette'in belirtmiş olduğu dört tekniğe de (özet, ara, eksilti ve sahne) rastlanır. Örneğin Pedro Tinoco'nun, Casimiro Huarcaya'nın ya da Doña Adriana'nın hikayelerinin anlatıldığı bölümlerde anlatıcı özetleme yaparak anlatıma hız katar ve bu kişilerin öyküsünü eserin zamanını aşan bir geçmişten başlayarak birkaç sayfaya sığdırarak özetler: "Yine de arkadaşlarının alaylarına ve ailesiyle olan kötü ilişkilerine rağmen, Casimiro, herhangi bir komplekse kapılmadan güçlü kuvvetli, el becerileri olan, uyanık ve hayata bağlı bir kişi olarak büyümüştü" (Vargas Llosa, 1996, s. 126). Ayrıca anlatıcının öyküden ayrılıp yorum ve betimlemeler yaparak ritmi düşürmesi ve öyküye ara vermesi eserin tamamında görülür. Anlatıcı her bölümde farklı anlatılara geçerek bir önceki anlatıyı yarıda keser. Eksilti kullanımı ise en fark edilir biçimde altıncı bölümün başında görülür. Bir önceki bölümde La Esperanza'ya gitmeye karar vermiş olan kahramanın oraya gidişi ve vardığı anda yaşadıkları anlatılmaz, yaklaşık bir günlük süre atlanır. Baş kahraman Lituma'nın birkaç ay öncesine kadar Lima'da sürdürmekte olduğu yaşamı üzerine bilgi verilmemesi ise eksilti yöntemine bir başka örnek olarak gösterilebilir. Zaman zaman Piura'daki hayatını hatırlasa da orada yaşadığı olayların üzerinden atlanır ve detaylara yer verilmez:

(...) Benimse Piura'dan getirdiğim hiçbir anım yok. Ne beni özleyen tek bir Piuralı ya da Talaralı var, ne de bu dünyada benim özlediğim tek bir kadın. (Vargas Llosa, 1996, s. 77)

Aylardır bu kadar nefis yemek yememişti; en azından Piura'daki günlerinden beri. (Vargas Llosa, 1996, s. 146)

Son olarak sahne yöntemi, olayların diyaloglarla aktarıldığı kısımlarda -özellikle Tomás'ın Mercedes ile yaşadıklarını anlattığı bölümlerde-görülür. Kısa bir zaman dilimini kapsayan diyaloglar atlama yapılmadan aktarılır ve olaylar ayrıntı kazanır.

Eser, anlatıdaki olayların gerçekleşme derecesini ve tekrarları ifade eden sıklık bakımından değerlendirildiğinde, romanın ağırlıklı olarak tekil anlatı ile aktarıldığı görülür. Ancak kimi yerlerde tekrar eden ve yinelemeli anlatıya da yer verilmiştir. Özellikle önem taşıyan olaylar tekrar eden anlatı biçiminde farklı kısımlarda birden fazla kez 
anlatılarak okurun karşısına çıkarılır. Bu örnekler, Aydınlık Yolcuların gerçekleştirdiği saldııların ve gulyabaniler, apular gibi doğaüstü varlıklar tarafından yapıldığına inanılan kötülüklerin vurgulanması çerçevesinde ilerler. Böylece, üç kayıp kişinin akıbetinin, bölgede hakim olan bu iki şiddet kaynağından biriyle bağlantılı olabileceği hissettirilir. Aydınlık Yolcular tarafından Andamarca'da gerçekleştirilen saldırı bu örneklerden biridir:

Ya teröristler bu gece Naccos'a düşüp de Andamarca'da yaptıkları gibi toplu yargılamalar yapmaya kalkışırlarsa? (Vargas Llosa, 1996, s. 59)

Daha sonra yargılamalar başladı. Listedekilerin dışında, hırsızlıkla, zayıflarla yoksulları istismar etmekle, zina yapmakla ve bireysel kötü alışkanlıkları olmakla suçlanan daha başkaları da tüm kasaba halkından oluşan mahkemenin karşısına çıkmak zorundaydı. (Vargas Llosa, 1996, s. 67)

Yinelemeli anlatı ise eserde ağılıklı olarak kullanılmamıştır ancak dikkati çeken en belirgin örnek, Bayan d'Harcourt'un öyküsünün konu edildiği bölümdedir. Gönüllü çalışmalar yürüten bir bilim insanı olan bu kişinin, bir süredir düzenli olarak And Dağları'na gerçekleştirmekte olduğu tehlikeli seyahat yılardır tekrarlanmaktadır ve eserde bir kez anlatılır:"Bayan d'Harcourt, o sabah erkenden, daha önceki yolculuk ya da gezi günlerinde olduğu gibi, saat çalmadan birkaç saniye önce, ortalık henüz karanlıkken kalkmıştı" (Vargas Llosa, 1996, s. 90).

\section{Anlatım/Anlatıcı (Kip ve Ses)}

Eser anlatı kipinin ilk kavramı olan mesafe açısından değerlendirildiğinde anlatıcının mesafesinin çeşitlilik gösterdiği ve dolaysız konuşma biçiminin (dolaysız diyalogların) oldukça ön planda olduğu fark edilir:"O zamanlar ben gençtim, Naccos madeni de terk edilmiş değildi (...)" (Vargas Llosa, 1996, s. 153). Kimi yerlerde ise yazar serbest dolaylı söylem ile kahramanın kendi iç konuşmasına sesini verir: "(...) Ama yine de öte tarafla ilgili bir şey söz konusu olduğunda kendini şaşkın ve huzursuz hissederdi hep. İnsanların hayatları el çizgilerinden okunabilir miydi acaba? Ya iskambillerden? Ya koka yapraklarından?" (Vargas Llosa, 1996, s. 119).

Perspektif ve odaklanma bakımından metnin geneline tanrısal konumdaki anlatıcı hakimdir ve olayları sıfır odaklanma ile aktarır. Bu konumdaki anonim anlatıcı her şeyi rahatlıkla görür, tüm düşünce ve konuşmalardan haberdardır. Öykülere dahil olmayan ve hakkında herhangi bir bilgi bulunmayan bu anlatıcı sürekli odak değiştirir ve her 
bölümde üçe ayrılan anlatılarda farklı bir karaktere içsel odaklanma yaparak öyküyü farklı açılardan sunar. Kimi zaman Lituma'nın, Tomás'ın kimi zamansa Bayan d'Harcourt'un ya da bir başka kahramanın gözünden öyküyü anlatır. Bu şekilde, bulmacanın parçaları yavaş yavaş bir araya gelir ve okurda giderek artan bir merak duygusu yaratılır. Ayrıca serbest dolaylı söylem sayesinde, özellikle Lituma'ya içsel odaklanma yapıldığı bölümlerde, anlatıcı ile karakter arasındaki sınırlar çok belirsizdir. Üçüncü tekil şahısta olmasına karşın anlatıya karakterin düşünme ve konuşma biçimi hakimdir. Vargas Llosa, konuşanın kim olduğu konusundaki bu belirsizlik ve karmaşanın bu tekniğin temelini oluşturduğunu ifade eder (Vargas Llosa, 1975, s. 88). Okur, anlattığı dünyanın dışında olup olmadığı çok net anlaşılamayan anlatıcının bu belirsizliği sayesinde dünyayı karakterin gözünden, onun sözleriyle algılamaya başlar ve kimi yerlerde anlatıının, karakterin kendisi olduğu algııına kapılabilir. Aşağıdaki alıntıda Lituma'nın yorumları oldukça ön plandadır:

Evet, Lituma da hissediyordu bunu. İşçilerin yüzlerinde tetikteymiş gibi bir ifade vardı, sanki kendilerini gözleyen bir düşmanı gafil avlamak ister gibi gözlerini bir sağa bir sola çeviriyorlardı (...) Acaba kayıp olayları yüzünden miydi? Yoksa içlerinden herhangi biri dördüncü olabileceği için mi korkuyorlardı? (Vargas Llosa, 1996, s. 123)

Anlatııı bazı bölümlerde ise okura bir film izletiyormuşçasına farklı zamanda ve/ya da farklı mekanda yaşananları aynı düzleme taşıyarak iç içe geçmiş bir şekilde aktarır. Aşağıda sırası bozulmadan verilen alıntıda bu duruma uyan bir kesit örnek olarak yer alıyor. (A) ile gösterilen kısımlarda eserin şimdiki zamanında Lituma diğer işçilerle beraber meyhanededir ve kayıp kişilerden biri olan Albino lakaplı Casimiro Huarcaya hakkında konuşulmaktadır. (B) ile gösterilen alıntıda ise Casimiro Huarcaya bilinmeyen bir geçmişte meyhaneye gelir ve okur bu şekilde Huarcaya'ya ne olduğunu öğrenir:

(A) - Şu albino Casimiro Huarcaya mı? -diye sordu Lituma-. Hani şu kaybolan? Hani şu gulyabani geçinen?

(B) Albino geç vakit meyhaneye girdiğinde, cumartesi geceleri her zaman olduğu gibi herkes körkütük sarhoştu. $O$ da öyleydi; insana tedirginlik veren o beyazımtırak kirpiklerinin altında kıpkırmızı görünen gözleri evinden uğramıştı (...)

(A) - O olmayacak da kim olacak? -diye karşılık verdi yüzü çiçek bozuğu olan işçi başını sallayarak-. Teröristlerin onu idam ettiklerini, sonra da tıpkı Hazreti İsa gibi dirildiğini bilmiyor muydunuz? (Vargas Llosa, 1996, s. 190) 
Vargas Llosa Conversación en la catedral (Katedralde Sohbet), Kent ve Köpekler, La fiesta del chivo (Teke Şenliği) gibi diğer eserlerinde de rastladığımız bu tekniği bileşik kaplar tekniği olarak adlandırır. Birbirinden farklı zaman, mekan ve gerçeklik düzeylerinde gerçekleşen olayların, anlatııı tarafından aynı düzlemde eşzamanlı bir biçimde yan yana getirilmesi ve ayrı anlatılsalardı sahip olmayacakları bir anlam edinmeleri olarak açıklar (Vargas Llosa, 1997, s. 89). Esere, biraz daha geniş bir açıyla bakıldığında bu tekniğin birkaç paragrafla sınırlı olmadığı, tüm metne hakim olduğu ve metnin belkemiğini teşkil ettiği anlaşılır. Anlatıda her bölümde kesitler halinde aktarılan farklı olay örgüleri sayesinde geçmiş ile şimdi, orası ile burası hiç durmadan iç içe girer ve böylece eserin sonunda birbirine bağlanarak tamamlanacak labirente benzer bir yapı oluşturur.

Bununla birlikte, bileşik kaplar tekniği, hikaye içinde hikayeler yaratmaya olanak sağlaması sebebiyle anlatıda bir başka tekniğin de yolunu açar. Yazarın matruşka ya da Çin kutuları olarak adlandırdığı bu yöntemde, gittikçe küçülerek birbirinin içine geçen öyküler, matruşka bibloları ya da Çin kutuları gibi sonsuza dek sürebilir. Bu tür bir yapı ise, öykünün içeriğinde gizem, anlam belirsizliği ya da karmaşıklık gibi etkiler yaratırken metnin yaratıcılığını arttıır (Vargas Llosa, 1997, s. 73). Böylece, hikaye içinde hikaye anlatan karakterler, metnin 6., 7., 8. ve 9. bölümlerindeki ikinci anlatılarında olduğu gibi kendileri de birer anlatıcı haline gelirler. Belirtilen bu bölümlerde anlatıcının konumu farklıdır; anlatıcı, öyküyü meyhanede çevresine toplanan madencilere anlattığı çıkarılabilecek Doña Adriana karakteridir ve ben anlatım konumundadır. Ancak bu konumdaki anlatııının sahip olduğu odaklanma konusunda bir belirsizlik vardır. Zira Doña Adriana sınırlı bir içsel odaklanma ile değil, tıpkı tanrısal konumdaki anlatıcı gibi sıfır odaklanma ile öyküyü anlatır. Öykünün tüm detaylarına hakimdir ve her an her yerdedir. Bu anlatıının aktardıkları sayesinde, kayıp kişilere ne olduğuna dair soru işaretleri yeni bir yön kazanır ve bazı öykülerin zamansal olarak daha öncesi/başlangıcı açıkığa kavuşur:

Köy halkından bir grup, başlarında babam olduğu halde, büyük çabalardan sonra oraya kadar inmeyi başarmıştı. Arabanın dört lastiğini, yaylarını, kasanın yamru yumru olmuş tenekelerini, karoserini ve motorun parçalarını çevreye saçılmış olarak bulmuşlardı ama Salcedo'nun cesedinden eser yoktu. (...) Aslında Quenka'da, yardan aşağı uçtuğu aynı tepedeki çok eski bazı mağaraların içine yerleşmişti, hani şu duvarlarında eski insanlardan kalma resimler olan, arı peteğine benzer mağaralarda. (Vargas Llosa, 1996, s. 177) 
Genette'in ses başlığında yer alan şahıs kategorisine göre, tanrısal konumdaki anlatıcının metni aktardığı bölümlerde anlatıcı heterodiegetik, ben anlatıcının bölümlerinde ise homodiegetiktir, bu kısımlarda anlatıcı öyküye dahil bir karakterdir ve kendi öyküsünü anlatır. Anlatılama zamanı olarak ise, metnin başında anlatıcı şimdiki zaman içerisindedir ve eşzamanlı bir anlatımı tercih eder. Ana olay örgüsü, kaybolan üçüncü kişi olan Medardo Llantac'tan haber alınamadığını bildirmeye karakola gelen karısının Lituma ve Tomás ile görüşmesi ile eşzamanlı olarak başlar ve ardından, anlatının devamında, önceden gerçekleşmiş olaylara yer verilerek sonradan öykülemeye de başvurulur. Hem tanrısal konumdaki anlatıcı hem de kahraman anlatıcı Doña Adriana belirli bir şimdiki zamandan hareketle geriye dönüşlerle olayları aktarırlar. Bu sebeple, araya giren öykülemenin esere hakim olduğu görülür. Örneğin, kayıp kişilerden biri olan Pedro Tinoco anlatımın başlangıcından önce kaybolmuştur ve anlatıcı 2. bölümün ikinci anlatısında bu kahramanın geçmişine yer verir: "Pedrito Tinoco'ya çocukluğundan beri kaçık, gerzek, kafadan kontak, ahmak, hep ağzı açık dolaştığı için de ayran budalası derlerdi (Vargas Llosa, 1996, s. 42).

Ayrıca eserde farklı anlatı düzeyleri yer alır. Hikayede yer almayan dış-öyküsel anlatıcının bulunduğu konum extradiegetik düzeyi oluşturur. Bu anlatıcı tarafından Lituma'nın yürüttüğü soruşturmanın, bölgede Aydınlık Yol gerillaları sebebiyle yaşanan şiddet olaylarının (iki Fransız turistin ve Bayan d'Harcourt'un başına gelenler) ve kayıp kişiler olan Casimiro Huarcaya, Medardo Llantac ile Pedro Tinoco'nun anlatıldığı birbiriyle bağlantılı öyküler metadiegetik düzeyde yer alır. Tomás ile Mercedes'in aşk hikayesi ise bu öyküden ayrı ilerleyen bir başka metadiegetik düzey olarak düşünülebilir. Okur anlatı boyunca iki ayrı hikayeyi de birbirinden bağımsız olarak takip eder. Nihayet eserin sonunda Mercedes'in Naccos'a Tomás'ı görmeye gelişiyle birlikte iki öykü birbirine bağlanarak bütünleşir: "Ne şanslı adamdı şu yardımcısı; basit bir jandarma eriyken bu harika kadın onu sevdiğini söylemek için kalkıp dünyanın bu ucuna kadar gelme zahmetine katlanıyordu. (...) Sevincinden düşüp bayılacaksın Tomasito" (Vargas Llosa, 1996, s. 246). Roman kahramanlarından biri olan Doña Adriana'nın anlattığı Dionisio'nun öyküsü ile gulyabani Salcedo'nun öldürülüş hikayeleri ise ikinci dereceyi oluşturur ve metadiegetik düzeyde yer alır. Genette, metadiegetik anlatıyı içine yerleştirildiği ilk anlatıya bağlayabilen belli başı ı ilişki türlerinden bahsetmektedir (Genette, 2011, s. 252-253). Buna göre eserde Genette'in tanımladığı ilk ilişki türü görülür: Üst-hikayenin olaylarıyla iç-hikayenin olayları arasında doğrudan bir nedensellik vardır ve ikinci anlatı, kendisinin de içinde olduğu hikayeyi anlatan bir karakter tarafından açıklayıcı bir işlev yüklenmiştir. Doña Adriana Naccos bölgesinin yakın geçmişini, Lituma'nın gelişinden 
öncesini aktarmaktadır: "O zamanlar ben gençtim, Naccos madeni de terk edilmiş değildi; bölgenin her yanından, hatta Pampas, Acobamba, Izcuchaca, Lircay gibi uzak yerlerden gelen madencilerle tıklım tıklım doluydu" (Vargas Llosa, 1996, s. 153).

\section{Sonuç}

Bu çalışmada, Mario Vargas Llosa'nın And Dağları'nda Terör romanına anlatıbilimsel bir çerçeveden yaklaşarak eseri, Gérard Genette'in Anlatının Söylemi adlı inceleme yönteminde belirttiği Düzen, Süre, Sıklık, Kip, Ses kategorilerine göre incelemeye ve anlatının farklı yönlerini, kendine has özelliklerini ortaya çıkarmaya çalıştık. Eserin ilk ve en belirgin yönü, iç içe geçmiş öykülerin labirente benzer bir yol izlediği karmaşık ve sürükleyici bir yapıya sahip oluşudur. Lituma'nın yürüttüğü soruşturma sırasında ortaya çıkan bu öyküler anlatının labirentleşmesini sağlayan ve farklı zamanları/mekanları bir araya getiren en önemli unsurdur. Böylece yazar eserin ilk bölümlerinde, kaybolan üç kişinin faillerinin Aydınlık Yol gerillaları olabileceğini düşündürürken sonraki sayfalarda apular, gulyabaniler, dağların iyi/kötü ruhları ve bu ruhlara insan kurban edilmesi gibi efsaneler ile doğaüstü varlıkları da anlatıya dahil ederek gittikçe daha dolambaçlı bir yol oluşturur. Doña Adriana tarafından anlatılan, kaçırdığı insanların bedenlerindeki yağları emip bitiren ve beyinlerini söküp alan gulyabani Salcedo'nun hikayesi gibi birçok başka doğaüstü öykü, kayıpların sebebi bu olabilir mi sorusunu sordururken, Aydınlık Yolcuların bölgede gerçekleştirdiği infazlar ve şiddet eylemleri de devam eder. Romanın başkahramanı -eserin sonunda her şey açıklığa kavuşuncaya kadar- yürüttüğü bu soruşturmada giderek şüpheler ve soru işaretleri içine düşer ve okuru da anlatı boyunca beraberinde sürükler.

Zamansal çerçeve bakımından, birçok bölümde anlatııı, anakronik bir anlatı düzenine başvurarak kurmacanın süredizimsel sırasını bozar ve her bölümde, birbiriyle bağlantılı olan, farklı açılardan birbirini tamamlayan öykülerin bulunduğu üç ayrı anlatı yer alır. Birinci anlatı kronolojik olarak belli bir sırayı takip ederken ikinci ve üçüncü anlatının zamansal düzeni tam olarak net değildir; karmaşık bir yol izlenerek zamanda ileri ya da geri gidişlerle kronolojik sıra bozulur. Anlatıdaki perspektif ve odaklanma incelendiğinde ise, metnin geneline tanrısal konumdaki anlatıcının hakim olduğu ve olayları sıfır odaklanma ile aktardığı görülür. Öykülere dahil olmayan bu anlatıcı sürekli odak değiştirir ve her seferinde ayrı bir konuya yer vererek öyküyü farklı açılardan sunar. Bulmacanın parçaları bu şekilde yavaş yavaş bir araya gelirken okurda merak duygusu canlı tutulur. 
Son olarak anlatıdaki yapısal özelliklerden bir diğeri de anlatıcının bazı bölümlerde farklı zaman ve mekanda yaşananları aynı düzleme taşıyarak iç içe geçmiş bir şekilde aktarmasıdır. Vargas Llosa birçok başka romanında da kullandığı bu tekniği bileşik kaplar tekniği olarak adlandırır. Hikaye içinde hikayeler yaratmaya olanak sağlayan bu teknik, Çin kutuları olarak bilinen başka anlatımların da yolunu açar. Bir bakıma 6., 7., 8. ve 9. bölümlerin ikinci anlatılarında anlatıcının değişmesi ve eserin kahramanlarından biri olan Doña Adriana'nın ben anlatım konumunda bir anlatıcı haline gelmesi bunun bir uzantısı olarak değerlendirilebilir. Ayrıca, Dionisio'nun öyküsü ile gulyabani Salcedo'nun öldürülüş hikayelerinin anlatıldığı bu bölümler eserde metadiegetik düzeyde yer alır ve Genette'in bu çerçevede tanımlamış olduğu gibi, üst-hikayenin olaylarıyla iç-hikayenin olayları arasında doğrudan bir nedensellik vardır. Buna göre, metadiegetik düzeydeki anlatı, kendisinin de içinde olduğu hikayeyi anlatan bir karakter tarafından açıklayıcı bir işlev yüklenmiştir.

\section{Hakem Değerlendirmesi: Dış bağımsız.}

Çıkar Çatışması: Yazar çıkar çatışması bildirmemiştir.

Finansal Destek: Yazar bu çalışma için finansal destek almadığını beyan etmiştir.

Peer-review: Externally peer-reviewed.

Conflict of Interest: The author has no conflict of interest to declare.

Grant Support: The author declared that this study has received no financial support.

\section{Kaynakça}

Çıraklı, M. Z. (2015). Anlatıbilim: Kuramsal Okumalar. Ankara: Hece Yayınları.

Dervişcemaloğlu, B. (2016). Anlatıbilime Giriş. İstanbul: Dergah Yayınları.

Genette, G. (2011). Anlatının Söylemi: Yöntem Hakkında Bir Deneme. (F. B. Aydar, Çev.). İstanbul: Boğaziçi Üniversitesi Yayınevi.

Gnutzmann, R. (2007). Novela y cuento del siglo XX en el Perú. Alicante: Cuadernos de América sin nombre.

Kıran, A. E. ve Kıran, Z. (2011). Yazınsal Okuma Süreçleri. Ankara: Seçkin Yayıncılık.

Mario Vargas Llosa. (2021). Britannica içinde. Erişim adresi: https://bit.ly/37nBnqq.

Sanabria, L. (2011). Los impostores del poder en La ciudad y los perros de Mario Vargas Llosa. Espéculo, 47, Erişim adresi: http://bit.ly/2uNT54c.

Vargas Llosa, M. (1996). And Dağları́nda Terör. (İ. Kut, Çev.). İstanbul: Can Yayınları.

Vargas Llosa, M. (1997). Cartas a un joven novelista. Barcelona: Editorial Planeta.

Vargas Llosa, M. (1975). La Orgía Perpetua, Flaubert y Madame Bovary. Barcelona: Editorial Seix Barral S.A. 
